\title{
Can you Hear me now?- A Unseen Truth
}

\author{
Siddharth Tevatia* \\ Department of Periodontology and Oral Implantology, ITS Dental College, India
}

Submission: September 07, 2017; Published: September 25, 2017

*Corresponding author: Siddharth Tevatia, Department of Periodontology and Oral Implantology, ITS Dental College, Muradnagar, India, Email: dr.siddharthtevatia@gmail.com

\section{Abstract}

Dental professionals are at risk for noise- induced hearing loss. Often, individuals are not aware that they have hearing loss their first complaint and the reason they seek a hearing evaluation may in fact be tinnitus. The dental office environment subject's dental professionals to noises associated with hand pieces and ultrasonic's as well as other dental equipment. Hand pieces must be well maintained to reduce the level of noise emanating from them. Hearing protection devices can be used to help prevent hearing loss. Several types are available, and musician's earplugs may be particularly useful as they reduce noise while still enabling the individual to hear and communicate with others.

Keywords: Noise; Hearing damage; Dental practice

\section{Introduction}

The National Institute for Occupational Safety and Health (NIOSH) has identified noise as one of the ten leading causes of work related diseases or in $\neg$ juries. Noise can cause masking of unwanted sounds, interference with speech and communication, pain and injury, and temporary and permanent hearing loss [1]. Prolonged exposure to noise can lead to noise- induced hearing loss (NIHL) and it may be undetected for years since it is estimated that individuals lose about $28 \%$ of hearing before becoming aware of the problem [2]. As dental professionals, we encounter several occupational hazards every day. Hearing loss is definitely one of them and which is ignored by dentist. Our hearing might be at risk due to the various noises encountered in our dental practice that may make us susceptible to the development of permanent hearing loss. Noise is an acoustic phenomenon which mainly arises in a gas, solid or, on occasion, liquid environment. We are all accustomed to everyday "normal noise", which are constantly present all around us. Apart from normal noise we as dental professionals have to encounter noises which are always present in our dental offices. 'Noise or sound intensity is measured in decibel (dB) [3].

\section{Production of noise in dental office}

Dental setup there is various sources which produce noise such as high speed hand pieces, high velocity suction, ultrasonic scalar and cleaner, mixing devices and model trimmers. Kilpatrick has listed the decibel ratings for various office instruments and equipment, which amount to 70-92 dB for high- speed turbine hand pieces, $91 \mathrm{~dB}$ for ultrasonic cleaners, $86 \mathrm{~dB}$ for ultrasonic scalers, $84 \mathrm{~dB}$ for stone mixers and $74 \mathrm{~dB}$ for low- speed hand pieces [4] Table 1.

Table 1: Production of noise in dental office.

\begin{tabular}{|c|c|}
\hline \multicolumn{2}{|c|}{ Effects of Noise } \\
\hline Auditory effects: & Non Auditory Effects: \\
Auditory Fatigue (90dB or & Interference with speech \\
$4000 \mathrm{~Hz})$ & Annoyance \\
Deafness- Temporary (4000- & Reduction in efficiency \\
$6000 \mathrm{~Hz})$ & Physiologic damage (increased \\
intracranial \\
Permanent (100dB) \\
pressure, increased heart rate, \\
headache etc)
\end{tabular}

\section{Types of Hearing Loss Induced by Noise [5]}

Ear can be injured by noise in 2 different ways, depending on the type of exposure. High- level, short duration exposures exceeding $140 \mathrm{~dB}$ can stretch the delicate inner ear tissues beyond their elastic limits, then rip or tear them apart. This type of damage acoustic trauma occurs rapidly and results in an immediate, permanent hearing loss. The second type of injury is due to exposure to noise between 90 and $140 \mathrm{~dB}$ damages the cochlea metabolically rather than mechanically and causes damage relative to the level and duration of exposure. Noiseinduced hearing loss, in contrast to acoustic trauma, develops slowly over years, is caused by any exposure regularly exceeding a daily average of $90 \mathrm{~dB}$, and proceeds in 3 stages. 
In the first stage, sensory cells within the cochlea are damaged by excessive exposure. These cells do not regenerate; they are replaced by scar tissue. In the second stage, after weeks to years of excessive exposure, hearing loss can be detected audiometrically. Early loss occurs in the high- frequency range, around the highest $\mathrm{C}$ note played on a piano. Speech comprehension is not significantly affected; therefore, this loss is seldom noticed unless hearing is tested for some other reason. With continued exposure, the loss spreads to the lower pitches necessary for understanding speech. At this point, the third stage, the patient usually becomes aware of the problem and may seek medical attention. Unfortunately, much of the damage has already occurred.

\section{Noise control in dental operatory}

Noise monitoring should be done with noise dosimeters routinely in the dental operatory Table 2 [6-10] and necessary measures to reduce noise should be taken [11].

Table 2: Noise control in dental operatory.

\begin{tabular}{|c|c|}
\hline Author & Review of Literature \\
\hline Bahannan S [1] & $\begin{array}{c}\text { According to a study, the laboratory machines } \\
\text { produced more noise }(81.42 \mathrm{~dB}) \text { compared } \\
\text { to laboratory electromotor }(74.95 \mathrm{~dB}) \text {, } \\
\text { turbine handpiece }(72.91 \mathrm{~dB}) \text { and low speed } \\
\text { handpiece }(69.71 \mathrm{~dB}) \text { creating a greater risk to } \\
\text { laboratory technicians working for more than } \\
8 \text { hours }\end{array}$ \\
\hline $\begin{array}{c}\text { Wilson [6] \& Trenter } \\
\text { SC [7] }\end{array}$ & $\begin{array}{l}\text { Some authors have proposed that ultrasonic } \\
\text { scalers may be a potential hazard to the audi- } \\
\text { tory system of both clinicians and patients }\end{array}$ \\
\hline Kadankuppe S [8] & $\begin{array}{c}\text { The results of another study found } \\
\text { sig } \neg \text { nificant differences in the noise levels at } \\
6 \mathrm{~m} \text { and } 2 \text { inches from the operator ear, the } \\
\text { laboratory engines producing the highest } \\
\text { noise }\end{array}$ \\
\hline Singh et al. [9] & $\begin{array}{l}\text { Dental laboratory machine, dental hand-piece, } \\
\text { ultrasonic scalers, amalgamators, high speed } \\
\text { evacuation, and other items produce noise at } \\
\text { different sound levels which is appreciable. } \\
\text { The noise levels generated varied between } \\
72.6 \mathrm{~dB} \text { in pre-clinics and } 87.2 \mathrm{~dB} \text { in prosthesis } \\
\text { laboratory. Although the risk to the dentists is } \\
\text { lesser, but damage to the hearing is possible } \\
\text { over prolonged periods. }\end{array}$ \\
\hline Qsaibati L [10] & $\begin{array}{l}\text { In dental clinics, the highest noise was } \\
\text { produced by micro motor handpiece while } \\
\text { cutting on acrylic }(92.2 \mathrm{~dB} \text { ) and lowest noise } \\
(51.7 \mathrm{~dB}) \text { was created by ultrasonic scaler } \\
\text { without suction pump. The highest noise in } \\
\text { laboratories was caused by sandblaster ( } 96 \mathrm{~dB} \\
\text { at a distance of } 15 \mathrm{~cm}) \text { and lowest noise by } \\
\text { stone trimmer when only turned on ( } 61.8 \mathrm{~dB} \\
\text { at a distance of } 2 \mathrm{~m}) \text {. There was significant } \\
\text { differences in noise levels of the equipment's } \\
\text { used in dental laboratories and dental } \\
\text { learning clinics (P =0.007). The highest noise } \\
\text { level recorded in clinics was at pedodontic } \\
\text { clinic }(67.37 \mathrm{~dB}) \text {. }\end{array}$ \\
\hline
\end{tabular}

\section{Control at noise source}

Application of muffles, Hand pieces should be well maintained Compressors should be fitted away from the work place. The design of the surgery should locate compressors, ultrasonic instrument cleaners and other equipment outside or in an isolated part, whereas the arrangement of the equipment inside the office should not result in an interference of sounds produced by them [11].

\section{Control of transmission}

Sound absorbing material wall Resilient floors sound proof acoustical ceiling sound- dampening materials ought to be used for finishing the walls and ceilings of offices [11].

\section{Protection of Exposed Person}

Simultaneous use of several turbines should be avoided dental drills should be kept $35 \mathrm{~cm}$ away from ear. Ear plugs and muffs Audiography test periodically for early detection. The dentist should maintain a proper distance from the operating field. Kilpatrick recommends the distance from the dentist's eye to the patient's mouth to be 14 inches, i.e. about $35 \mathrm{~cm}$ [4]. When the operator is closer, decibel rating increases. Miranda mentions other controllable variables: how the ear is oriented to the working field, the orientation of hand piece exhaust ports to the ears, and the position of the hand piece in relation to the mouth. The rotary instruments must be activated only when they are ready to be used [12].

\section{Conclusion}

The American Dental Association Council on Dental Research advised that dentists using high speed drills should have periodic hearing tests to monitor their hearing [13]. Further recommendations include minimizing non- occupational noise exposure and using a hearing protection device when exposed to loud sounds. Dental professionals can protect their hearing while at work by monitoring and/or changing the environment to decrease the effects of noise. To ensure that the effects of noise are diminished, using a hearing protection device when exposed to noisy dental equipment may prevent the occurrence of noiseinduced hearing loss.

\section{References}

1. Bahannan S, Hamid AA, Bahnassy A (1993) Noise level of dental handpieces and laboratory engines. J Prosthet Dent 70(4): 356-360.

2. Setcos JC, Mahyuddin A (1998) Noise levels encountered in dental clinical. cal and laboratory practice. Int J Prosthodont. 11(2): 150-157.

3. Szymanska J (2000) Work related noise hazards in the dental surgery. Ann Agric Environ Med 7(2): 67-70.

4. Kilpatrick HC (1981) Decibel ratings of dental office sounds. J Prosthet Dent 45(2): 175-178.

5. Clark WW, Bohne BA (1999) Effects of noise on hearing. JAMA 281(17): 1658-1659.

6. Wilson JD, Darby ML, Tolle SL, Sever JC (2002) Effects of occupational ultrasonic noise exposure on hearing of dental hygienists: a pilot study. J Dent Hyg 76(4): 262-269. 
7. Trenter SC, Walmsley AD (2003) Ultrasonic dental scaler: associated hazards. J Clin Periodontol 30(2): 95-101.

8. Kadankuppe S, Bhat PK, Jyothi C, Ramegowda C (2011) Assessment of noise levels of equipments used in the dental teaching institution, Bangalore. Indian J Dent Res 22(3): 424-431.

9. Singh S, Gambhir RS, Singh G, Sharma S, Kaur A, et al. (2012) Noise levels in a dental teaching institute-A matter of concern! J Clin Exp Dent 4(3): e141-e145.

This work is licensed under Creative Commons Attribution 4.0 Licens

DOI: 10.19080/MABB.2017.02.555589
10. Qsaibati L, Ibrahim O (2014) Noise levels of dental equipment used in dental college of Damascus University. Dent Res J (Isfahan) 11(6): 624630.

11. Wagner H (1985) How healthy are today's dentists? JADA 110: 17-24.

12. Miranda FJ (1985) Protect your hearing. Dental office sounds may be hazardous to your health. J Okla Dent Assoc 75(3): 38-39.

13. (1997) Prevention of noise induced hearing loss [monograph on the internet]. World Health Organization, Geneva.

\section{Your next submission with Juniper Publishers will reach you the below assets}

- Quality Editorial service

- Swift Peer Review

- Reprints availability

- E-prints Service

- Manuscript Podcast for convenient understanding

- Global attainment for your research

- Manuscript accessibility in different formats

( Pdf, E-pub, Full Text, Audio)

- Unceasing customer service

Track the below URL for one-step submission https://juniperpublishers.com/online-submission.php 